\title{
The Effect of Locus of Control, Learning, and Adversity Quotient Towards Micro Business Success (Study on Entrepreneurship under Foster Group of the Banjarmasin)
}

\author{
TITIEN AGUSTINA, WIDA GERHANA, AND SULAIMAN
}

Sekolah Tinggi Ilmu Manajemen Indonesia, Banjarmasin

\begin{abstract}
Micro, small and medium entrepreneurs are the economic drivers at the lower levels and they generally rely on the ability of human resources. Nevertheless, they will be extraordinary if all their potential is nurtured, explored and developed because the factors that trigger success are not only determined by external conditions, but also internal conditions. Among the internal factors that spur one's success are locus of control, learning, and adversity quotient. This study aims to examine the partial and simultaneous effects of locus of control, learning, and adversity quotient on business success. The research respondents were a foster group of entrepreneurs under Banjarmasin, total 1881 people. With the Slovin formula, 100 respondents appear. The results of the study showed partially that the t value of the effect of locus of control on business success was 3.046. T value calculated the effect of learning on business success was 2,150 . T value calculated the effect of adversity quotient on business success was 4.924 . Thus, adversity quotient had the most dominant influence on business success. The correlation coefficient of 51,944 and the probability value between variables of 0,000 indicate a significant effect between locus of control, learning, and adversity quotient on business success simultaneously. Finally, it was found that R square 0.619 means $69.1 \%$ where business success can be explained by the locus of control, learning, and adversity quotient variables; the remaining $30.9 \%$ was explained by other factors. The research findings that the guidance provided must be ongoing, not only with training, but also need to foster mental and spiritual change as a true entrepreneurship through strong locus of control, continuous learning, and high adversity quotient.
\end{abstract}

Key words: micro, small and medium entrepreneurs; locus of control; learning; adversity quotient; business success

\section{INTRODUCTION}

Micro, small and medium scale business growth is very dominant in the national economy (Rindrayani, 2016). At the micro scale, the growth is the highest (Agustina, Chandrarin, \& Manan, 2017). Many problems had micro, small and medium scale businesses, such as limited working capital, poor quality of human resources, lack of expertise in the mastery of science and technology, education and limited experience (Hanim, 2002). This is also compounded by difficulties in marketing (Sholihin \& Mujilahwati, 2016), capital and marketing constraints (Maulida \& Yunani, 2018).

Correspondence Author: Titien Agustina. Sekolah Tinggi Ilmu Manajemen Indonesia (STIMI), Jl. Kuripan,

Banjarmasin, Email: titienagustina9@gmail.com
Some aspects of the strengths and weaknesses of micro, small and medium scale businesses, according to Tambunan (2002), involve humans and the economy. The strengths of micro, small and medium scale businesses from the human aspects are motivation in maintaining business and abundant labor supply but with low wages. The disadvantages are low quality of human resources, ow productivity level, low work ethic and discipline, the use of labor tends to be exploitative with the aim of pursuing targets, often relying on family members as unpaid workers. The strengths of micro, small and medium scale businesses from the economic aspects are relying on informal financial resources that are easily obtained, relying on new local ingredients, and serving lower-demand market segments. The weaknesses of the economic aspect was added 
value and poor accumulation and poor financial management.

It shows that the human resources of micro entrepreneurs are still low and this needs to be improved through various efforts to strengthen their competence and capacity in order to move up the class. The failure of micro entrepreneurs is not only due to external factors such as the environment and existing systems, but also originates from the self concerned or internal individuals (Agustina, 2019). There are many people who are able to achieve success, but there are some people who are unable to compete and fail. For this reason, it needs to be researched with the aim to find out what factors influence the birth of mindset of thinking and attitude, what factors encourage micro and small entrepreneurs to change and be able to be adaptive to changes in the surroundings, and why some people are able to withstand all problems and obstacles.

The willingness to continue learning is a capital for the human resources that drive micro, small, and medium businesses. This is expected to create the ability to manage problems, knowledge, and experience that can encourage creativity and initiative in innovation. Over time, this shows economic capability. In 2016 the growth of micro entrepreneurs reached $34.34 \%$ compared to 2015. It means that the presence of micro entrepreneurs in urban communities needs to be a concern of the government so that they can provide added value and support the city's economy that can be synergized with development programs. Consequently, the business drivers in the small and medium micro business cluster are able to respond to conditions, including a very volatile business world and this requires a change in mental attitude, insight and how to respond.

Suyanto and Chamdan (2010) that the success of small industrial businesses is influenced by various factors, such as financial performance and corporate image. Glancey in Sony Heru (2009) that entrepreneurs who have the ability to make superior decisions will be able to improve business performance such as increasing profits and business growth.
Suryana (2011) that to be a successful entrepreneur requires a clear idea or business vision, a willingness and courage to face the risks of both time and money. Erliah (2007) in Prihatin and Riyanti (2003) said that a business is said to be successful after a certain period of time the business has increased both in capital, business scale, results or profits, type of business and management. Sony Heru (2009) said that the ability of entrepreneurship combined with managerial ability will lead to success in business.

In addition to profits, business success can be seen from the targets achieved. Dalimunthe (Noersasongko, 2005) said that to be able to analyze the success of the business, it can be known through a comparison of the value produced by the company with the expected value through the utilization of available resources. Company performance is the output of various factors and this indicator becomes very important to know the level of adaptability of the business to its environment. Business performance needs to be linked to company targets determined by the business owner-manager. Whatever the target is, business performance is a benchmark to assess how much the level of achievement of a target or business goal is (Primiana, 2009; Faizal, 2007; Prihatin \& Riyanti, 2003; Suryana, 2011).

Factors that influence business success come from internal and external factors. Internal factors include the quality of human resources, organizational mastery, organizational structure, management systems, participation, business culture, capital strength, business networks with external parties, and the level of entrepreneurship. External factors include government and nongovernment, which is related to economic policy, bureaucrats, politics, and the level of democracy; non-governmental factors are the economic system, the socio-culture of the community, the labor system and labor conditions, the condition of infrastructure, the level of public education, and the global environment. 
Luk's research result in Suyanto (2010) that the determinant of the success of small industrial businesses is marked by innovation and risk-taking behavior. Murphy's research found that the success of small businesses is contributed by hard work, dedication, and commitment to service and quality. Various determinants of success of small-scale industry business results identified by Luk's research are, in essence, a reflection of business ability (knowledge, attitude, and skill), relevant experience, work motivation, and the level of education of a businessman. Business success is reflected through knowledge, attitudes, and skills of entrepreneurs. It means that the success of a business is not only seen physically but also felt in the form of personal vocation or inner satisfaction.

The significant criteria for determining business success (Prihatin \& Riyanti, 2003) was increasing in capital accumulation or in capital, the amount of production, number of customers, business expansion, expansion of marketing areas, improvement of physical facilities, business income. Suryana (2011) that indicators of business success consist of capital, income, sales volume, production output, and labor. In this study, the dimensions of business success are an increase in capital accumulation or an increase in capital, the amount of production, the number of customers, business expansion, expansion of marketing areas, improvement of physical facilities, and business income (Prihatin \& Riyanti, 2003).

This research focuses on human resources who become entrepreneurs or activators of micro small and medium businesses themselves, especially micro businesses based on statistical data in many places, including Banjarmasin occupying a dominant number of other business clusters (Rindrayani, 2016; Agustina, 2019). This research explores what is in the mind and in the habits of micro small and medium entrepreneurs so that this builds beliefs and attitudes of a persons' behavior in business. It is important to know the locus of control owned by micro, small and medium business entrepreneurs, the spirit of learning that is owned, and adversity quotient that shows their fighting ability in facing obstacles and failures.

Locus of control was first formulated by Rotter (1966) and this was based on social learning theory. In this learning theory, Rotter thats three main aspects, namely potential behavior, expectation, and reinforcement value. Locus of control is a person's belief in the sources that control the events in life, i.e. whether the events that occur are controlled by external forces. This concept is distinguished between internal and external locus of control. Someone who has the belief that one's life is determined by chance, luck, and fate is called having an external locus of control. Otherwise, this is called an internal locus of control.

Rotter (1966) that locus of control is a person's assumption about the extent to which that person feels a connection between the efforts that have been made and the consequences received. If someone feels the relationship, this is said to have an internal locus of control, while the person who has an external locus of control will assume as a result received from the opportunity, luck, fate, or interference of others. It means that locus of control is one of the important aspects in the characteristics of human personality.

Generally, the dimensional continuum of locus of control moves from external to internal degrees, where the understanding of external locus of control leads to the belief that certain behaviors, results or events are caused by fate, luck and are determined by external or other forces. Individuals who have an external locus of control tend to conclude that something happens because of a power from outside themselves so that the individual is not responsible for the actions. These individuals tend to be reactive and reject situations that suppress themselves (Stoltz, 2000) so that individuals tend to be bound by maladaptive behavior patterns leading to self satisfaction that does not want to be linked between behavior and achievement of results.

Locus of control in essence can affect individuals in observing and interacting with 
the environment. Individuals who are asked for opinions on achieving the results of their behavior will connect between the locus of control and the cognitive processes that occur. Locus of control is based on what is observed and this has been owned during childhood and tends to change toward the external rather than internal. Locus of control orientation during adolescence tends to be more internal than adults (Skinner et al, 2008) so that it uses concrete cognitive reasoning more.

Locus of internal control has the following characteristics:

1) Feeling able to regulate all actions, deeds and the environment;

2) Diligent, resilient, independent and not easily influenced by outside influences;

3) More responsible for mistakes and failures;

4) More effective in completing tasks;

5) Having high confidence in abilities.

Whereas the characteristics of the external locus of control:

1) More resigned and comfrom to the environment;

2) Feeling that the actions are small affecting the events to be encountered and both undergo an unpleasant situation or are in an effort to achieve goals;

3) Less responsible for mistakes made;

4) Lack of confidence in abilities; and tending to rely on others.

Organizations that develop the capacity to adapt and change continuously are known as organizational learning. The concept of learning here includes organizational learning from micro small and medium businesses in responding to changing consumers' demands and high competitiveness in society. A micro small and medium business entrepreneur must have a strong interest and willingness to be able to build and improve self competence. One form of competency improvement is with organizational learning (Fathor \& Arief, 2017; Hendrawan et al, 2018).

Learning for micro entrepreneurs is very important. If an entrepreneur or micro business actor does not have a good learning orientation, he or she will experience many obstacles in the effort to build a good product/service, along with market needs. Micro entrepreneurs generally rely solely on the entrepreneurial spirit of their owners (Bustan, 2016) and in the future it needs to be followed by continuous learning efforts in building a business so that it will slowly and surely experience disruption (Agustina et al, 2018). Learning orientation for a micro, small and medium business/entrepreneur must always be a part of him or her at all times. If other people make changes, there will be continuous innovation on products/services and if entrepreneurs/microbusinesses do not want to learn from what other people or competitors are doing, this will naturally face obstacles and will sustainably have an impact on business decline. Consumers will usually move to other competitive products that are better, more attractive, and even cheaper.

Khandekar and Sharma (2006) that organizational learning is a process of gaining knowledge both personally and in groups to be applied to the work being done and this has an effect on forming a source of competitive advantage. The quality of organizational learning can be defined as the level of good or bad learning in an organization which is expected that each member collectively receives and collects information and knowledge according to the needs and abilities of each individual. They facilitate and act according to interpretation, producing something (output) that can be measured with number or that can be paired with number.

Organizational learning is very important to create competitive advantage (Agustina et al, 2017; Fathor \& Arief, 2017; Sinkula et al, 1997; Slater \& Narver, 1994). In the process of organizational learning, several people will co-exist with their thinking patterns and freely share ideas with others, form the organization's vision, and work together to plan the achievement of vision. Specifically, the learning process can be carried out through steps:

1) Building a commitment to change;

2) Adopting informal organizational structures; and 
Developing an open organizational culture. Learning organizations have different dimensions and characteristics from organizations that do not implement learning.

Many people dream for success, but not all people succeed through it and overcome obstacles in order to achieve success or success of the dream. For this reason, in addition to locus of control and learning, progress quotient (AQ), which means an awareness to be able to survive failure or obstacles, is needed. Surekha (2001) that adversity is the ability to think, manage, and direct actions shaping patterns of cognitive and behavioral responses to stimulus events in life that are challenges or difficulties.

Stoltz (2000) that adversity quotient is one of the intelligence that must be possessed by anyone in overcoming difficulties and is an attitude showing the ability of people to be able to overcome all difficulties and obstacles when someone experiences failure. The success and failure of individuals in life was determined by adversity intelligence where adversity intelligence can tell the extent to which individuals are able to survive and overcome difficulties faced; which individuals are able to overcome difficulties and who are unable; which individuals will fulfill their hopes and potential and who will fail; and individuals who will surrender and who will survive. Adversity intelligence for an entrepreneur/micro, small, and medium-sized business actor is needed in order to boost performance in the business being run (Agustina et al, 2017).

Stoltz (2000) that four dimensions of the Adversity Quotient, which was called CO2RE (Control, Origin Ownership, Reach, Endurance) that will be explained as follows:

\section{a) Control (C).}

This dimension focuses on the individual's perceived control of events that cause difficulties. High value on the control dimension indicates that the individual is able to control the events that occur in one's life, finds ways to deal with difficulties, never gives up, and is responsive in finding a solution.

b) Origin and ownership (O2)

\section{Origin}

This dimension focuses on the causes of difficulties. Origin is related to guilt. A high value on the origin dimension indicates that each individual has a hard time, considers the difficulty come out from outside party and learns from the mistakes made.

\section{Ownership}

This dimension focuses on recognizing the consequences caused by difficulties and the intention to take responsibility. High value on the ownership dimension indicates that individuals are willing to take responsibility and acknowledge the consequences of actions taken.

c) Reach (R)

This dimension focuses on the extent to which adversity will affect the other side of life. High value in the reach dimension indicates that the adversities encountered will not affect the other side of life and are expected to be able to respond bad events as specific and limited.

d) Endurance (E)

This dimension focuses on how long the difficulties and causes of these difficulties will last and the ability of individuals to survive when faced with difficulties. High score on the endurance dimension indicates that the individual is optimistic, considers difficulties and causes of difficulties as temporary, fleeting, and less likely to happen again and views success as ongoing or even permanent.

It means that success in any field is inseparable from the effort done well. If someone in taking action and decision is more determined by parties outside himself or herself (LoC), this condition at a certain time will put the person in a difficult position. However, if the decision and action are born from within themselves, based on experience, knowledge, beliefs, and optimism, it is called the internal locus of control. Therefore, the activities carried out should be more derived from abilities and beliefs in themselves, not by other parties outside themselves so that business success can be achieved properly if the person concerned is able to demonstrate self-quality (Agustina et al, 2017). Through 
learning in organization, it will be able to encourage the acceleration of changes in one's personality in the mindset and way of looking at something, especially in businesses very volatile requiring speed and accuracy in making business decision.

If an entrepreneur has a good learning orientation, it is expected to have an impact on increasing insight, knowledge, and understanding in the business being run (Agustina et al, 2017) so that the success of the business will be predictable because the relevant person is skilled and has the ability. With the support of strong self-confidence through a focus on good self-control (LoC), a good learning orientation can be used as a lesson and learning source, supported by high motivation through adversity intelligence so that business success can be achieved well.

\section{RESEARCH METHOD}

This research focus of dependent variable Business Success (Y) and independent variables which include Locus of Control $\left(\mathrm{X}_{1}\right)$, Learning $\left(\mathrm{X}_{2}\right)$, and Adversity Quotient $\left(\mathrm{X}_{3}\right)$. Through quantitative descriptive research, micro entrepreneurs as a foster group under regional government of Banjarmasin total 1881 people and 100 people had taken as samples. Data analysis techniques use:

a. Testing data quality through:

1) Validity test aimed to determine whether each item of questions or statements in the questionnaire really can reveal the variables studied;

2) Reliability test has a test of the stability of a measurement tool in measuring an answer from the respondent. The reliability test has carried out with the Alpha Cronbach test. Questions or statements that have a Cronbach Alpha of more than 0.6 said to be a reliable instrument;

b. Classical Assumption Test using the following steps:

1) Normality test aimed to test whether the regression model, confounding or residual variables have a normal distribution. The t test and $\mathrm{F}$ test that the residual value the normal distribution. To test whether the data is normally distributed or not, it has necessary to do the One Sample Kolmogrov Smirnov Test statistical test. Residuals normally distributed if a significant> 0.05 (Ghozali, 2016).

2) Heteroscedasticity test aimed to test whether in the regression model there were an inequality of variance from the residuals of one observation to another. If the variance from one observation residual to another observation were fixed, it was called homoscedasticity and if it is different, it were called heteroscedasticity; the testing method used was the Glester Test method (Ghozali, 2016).

3) Multicollinearity test have to find out whether there has a strong correlation between independent variables. To know the symptoms of multicollinearity between independent variables, one way has to look at the VIF value of each independent variable on the dependent variable. If the VIF value has less than 10 and the tolerance value $>0.10$, then the model has declared not to contain multicollinearity.

c. Regression Analysis

1) Determinant Coefficient (R2)

Determination Coefficient Test (R2) intended to measure how far the model's ability to explain the variation of the dependent variable (Ghozali, 2016). If R2 gets bigger (close to one), then the relationship of the independent variable large with respect to the dependent variable. The increasingly powerful model have the correlation of the independent variable to the dependent variable. If $\mathrm{R} 2$ found smaller, that the correlation between the independent variable and the dependent variable found smaller. It was that the model used not strong. In general, it was that the coefficient of determination (R2) between 0 and 1 or $0 \leq R 2 \leq 1$.

2) T test or partial test (t) used to show the extent of the influence of partially independent variables on the variation of the dependent variable (Ghozali, 2016)by comparing the value of $t$ calculated with a significant level of 0.05 . Probability value have obtained from the result of data processing through SPSS. 
3) The $F$ test or the simultaneous influence test to find out the joint effect of the independent variables (Ghozali, 2016). Test carried out using significance level $(\alpha=5 \%)$.

Thus, the hypotheses tested:

H1: Locus of control, learning, and adversity quotient partially have a positive effect on the success of micro entrepreneurs;

$\mathrm{H} 2$ : Simultaneous locus of control, learning, and adversity quotient have a positive effect on the success of micro entrepreneurs;

H3: Adversity Quotient has a dominant effect compared to locus of control and learning on the success of micro entrepreneurs.

\section{RESULTS AND DISCUSSION}

The result of the validity test of the learning variable instrument found the number above $r$ table so that all instruments was valid while the result of the instrument reliability test $r$ counts above $r$ table so that all instruments was reliable. The result of the Heteroscedasticity Test as shown from the regression analysis of the influence of Locus of Control, Learning, and Adversity Quotient on Business Success was points on the Partial Regression Plot Dependent Plot Dependent Variable Y: X1, X2, X3 and it was not form a specific pattern. It found that there has no heteroscedasticity.

The result of multicollinearity test of the independent variables (Locus of Control, Learning, and Adversity Quotient) has performed by comparing the VIF value with the number 10 . If the VIF value $<10$, it found that the data was not experience multicollinearity. VIF Locus of Control, Learning, and Adversity Quotient <10, so Locus of Control, Learning, and Adversity Quotient data was not experience multicollinearity. The result of the determinant coefficient found that the value of $\mathrm{R}$ which have cultivated (R2) x $100 \%$. R value squared $0.619 \times 100 \%=61.9 \%$, so $61.9 \%$ Business Success have influenced by the Locus of Control, Learning, and Adversity Quotient. The rest have $37.1 \%$ Business Success that have affected by other variables (error) outside this study.

The regression coefficient found the significance of the effect of Locus of Control (X1) on Business Success (Y) $0.003<0.05$, the significance of the effect of Learning (X2) on Business Success (Y) $0.034<0.05$, and the significance of the effect of Adversity Quotient (X3) on Business Success 0.00 $<0.05$. Thus, Locus of Control, Learning, and Adversity Quotient was a significant effect on Business Success partially.

Dominant variables could be predicted by comparing the calculated t value. $T$ value have the effect of Locus of Control on Business Success have 3,046. T value have the effect of Learning on Business Success have 2,150. T value have the influence of Adversity Quotient on Business Success have 4.924. The largest value of $t$ arithmetic have on the effect of Adversity Quotient on Business Success so that the dominant variable have on Adversity Quotient, while to test the simultaneous effect have required to use the $\mathrm{F}$ Test, where the $\mathrm{t}$ value found 51, 944 and $F$ table 2.68 with a significance of 0,000 . So, $F$ count $>F$ table with a significance of $0,000<0,000$ and it found the effect of Locus of Control, Learning, and Adversity Quotient on Business Success simultaneously.

The research findings found that Locus of Control, Learning, and Adversity Quotient has a significant effect on the success of micro entrepreneurs in Banjarmasin partially. Locus of Control by basing it self on the success achieved themselves inseparable from the efforts that have been made to achieve it. It was that micro entrepreneurs in Banjarmasin already has the ability to control themselves well to their own depositions (internal locus of control). It is in line with Rotter's view(1966) that the internal locus of control is an individual who can control the events that affect him or her. It is also in line with Sudarsono and Irawati (2003) and Wisesa and Indrawati (2016) that the internal locus of control has more positive effects. It is reinforced by Setiawan and Rini's research (2010), Agustina's research (2019) 
internal people are more active in seeking information and using it to control the environment so that they prefer to oppose influences coming from outside than people who have locus of external control which is more conform to these influences.

For people who have a strong internal locus of control, their tendency will not be easy to give up their destiny to circumstances. They are more positive and optimistic in seeing the world and its surroundings so that they are able to manage the influences that come well. Strong self-confidence through good self-control that fate is the choice of the choice decision that can actually be managed starting from the process of decision making. The step or attitude taken starts from the decision in determining the choice of steps.

Learning through willingness to continue learning and renewing knowledge and experience from anywhere and with anyone makes a dominant contribution in influencing the success of micro entrepreneurs in Banjarmasin. Knowledge and experience are determined from the education received, both formal and informal education (Utami, 2018) that the knowledge of micro and small business owners sourced from formal education has a positive and significant effect on the success of business performance when their knowledge is able to use for strengthening business success in achieving their micro, small and medium business goals.

Informal education can be obtained from training or courses. The micro entrepreneurs in Banjarmasin have participated in entrepreneurship training, both related to the addition of knowledge and skills in the fields of production occupied, in the fields of marketing, packaging, business licenses, additional business capital, taxation, building networks, and others. Implementing the knowledge gotten from both formal and informal can have an impact on changes in one's mindset and behavior, including on micro entrepreneurs so that the learning outcomes obtained are expected to bring changes to the business being run. It is in line with Bustan's research (2016) that learning for micro, small, and medium entrepreneurs becomes a force that is concerned in managing a business or business organization. The result of this study also found that learning that is accepted and becomes a part of one's soul or characteristics is closely related to personality traits of people so that this will have an impact on one's internal personality. In the end, this enriches the behavior of the business owner in developing one's business. The knowledge obtained is a form of accumulation of the learning process carried out. It is in line with the research of Sinkula et al. (1997) that through learning there will be a process of developing self ability.

Learning will be able to form a new set of values affecting one's desire to create and use the knowledge for success in the occupied field because the knowledge gained from learning will be a strength in itself. Through good learning for an entrepreneur, especially micro entrepreneurs, it will be able to drive increased success (Hill and McGrown, 1999: 167 in Bustan, 2016). Therefore, learning is a means to maintain and improve the quality of a person, including micro entrepreneurs in their participation in intense competition.

Thus learning by micro entrepreneurs in Banjarmasin becomes one of the strengths in building personality, business development, and competitiveness so that it is able to bring changes in creativity and innovation in responding to the demands of a competitive market. The result of this study is also in line with the Gregory's view (2004) in Bustan (2016) that the new knowledge acquired will be able to influence a person's behavior, including micro entrepreneurs under foster group of regional government of Banjarmasin.

Furthermore, the statement that God will not give difficulties beyond the limits of human ability in relation to Adversity Quotient has made a dominant contribution in influencing the success of micro enterpreneurs in Banjarmasin. It shows that the micro entrepreneurs under foster group of regional government of Banjarmasin have strong mental potential through the belief that God will not give difficulties beyond their abilities. 
It shows the existence of inner strength related to their faith in God through spiritual intelligence (spiritual quotient) so that it makes them able to survive from failure, able to get out of the problems hindering them in running a business. They can survive amid the recession of the country's economy and the global economy. The result of this study found the fact that micro, small and medium entrepreneurs are economic heroes who are able to survive in any difficult economic conditions.

Micro entrepreneurs who have been fostered by the Banjarmasin regional government have been able to accept and face difficulties and failures well. In addition to encouraging economic factors, it turns out that micro entrepreneurs'mentality also forms individuals who do not easily give up with circumstances and are not easily resigned to existing conditions. Through the learning process, it becomes one of the ways to build and form a strong mentality and maintain high motivation so that they are able to survive in the business shock that befalls. The result of this study also found that the micro entrepreneurs who was fostered by the Banjarmasin was high trust in God Almighty so that they can put the matter in a good and logical way. It means that there is adversity quotient and spiritual quotient so that they are able to keep them going.

The result of this study support Lasmono in Sunarya, Sudaryono, and Saefullah (2011) in Wisesa and Indrawati (2016) that in business or career it is not enough to rely on IQ and EQ in full manner, but AQ (Adversity Quotient) is needed. This is in line with Fahmi's view (2008) in Wisesa and Indrawati (2016) that people who have AQ are highly motivated people. Therefore, a high AQ is needed in entrepreneurs, including micro entrepreneurs to be able to respond intelligently to any conditions and put them in the correct proportions.

The result of this study support the results of research from Laura and Sunjoyo (Wisesa \& Indrawati, 2016) that high-performing workers are also determined by high AQ levels. It is in line with the results of research showing that a micro entrepreneur who has a high adversity quotient, coupled with a good spiritual quotient, is more motivating fighting spirit and better effort (action). Good spiritual intelligence forms a high sense of dependence on the God he or she believes where this belief breeds the behavior of trying as hard as possible to get maximum results. It can happen when there is already a good understanding and religious belief that humans may plan, but related to the results of efforts, it is God's realm to give/grant it or not.

Micro entrepreneurs in Banjarmasin already have good religious beliefs. It cannot be separated from the origins of the population of Banjarmasin where the majority are ethnically Banjarese and are known as religious communities (Suryaputera, 2014). For people with high adversity quotient, it is categorized by Stoltz (2000) as a type of climbers, for people who are referred to as humans reaching the peak of self-actualization needs, according to hierarchy Maslow's theory. It explains that micro entrepreneurs in Banjarmasin have a high adversity quotient with the type of climbers so that they can be categorized as personal not giving up easily. It is in line with Sunarya's view, et al (2011) in Wisesa and Indrawati (2016) that entrepreneurs who want to succeed and can survive in the entrepreneurial world should try to become climbers entrepreneurs as mentioned by Stoltz (2000) as being smart in facing obstacles in order to determine the ability to survive and climb difficulties and success. It is also in line with Akbar's view (2009) in Wisesa and Indrawati (2016) stating that individuals having high adversity quotient can reduce negative thinking factors such as thinking they are unable to overcome problems and thinking about bad things that will happen.

The results found that all independent variables has a positive and significant effect on business success. Through good control (locus of control), the success achieved cannot be separated from the efforts that have been made. If micro entrepreneurs want to succeed, 
they must work hard and work smartly. Nevertheless, micro entrepreneurs are very aware that business success can be achieved when it is pursued with concrete steps. Supported by attitude and willingness to continue learning and renewing knowledge and experience, it further strengthens the entrepreneurs'mental building.

The potential for mentality is further supported by high adversity quotient shown from the belief that God will not give difficulties beyond one's ability. Such thing becomes a source of strength from the person concerned. Through the process of time, it will be able to shape the successful entrepreneurs' mindset, form a positive attitude, be optimistic, be creative, and be enthusiastic in addressing every problem they face. It means that the response growing and developing in people's personalities will be in line with the effort and effort or sacrifice given.

Thus, efforts to increase motivation and enthusiasm in entrepreneurship was to build the entrepreneur's human resources from their internal selves. This becomes important to explore the entrepreneur's spirit maximally in order to be useful and qualified. For this reason, micro-entrepreneurial human resources need to develop and explore their potential to become qualified human beings psychologically, starting with mental development or mental entrepreneurship development that is fully developed. How to develop Adversity Quotient in entrepreneurs by using LEAD formula (Listened, Explored, Analized, and Do) (Stoltz, 2000).

Developing one's Adversity Quotient especially for micro entrepreneurs who already have an interest and intention in entrepreneurship will definitely be easier. Through the learning process, supported by strong locus strengths and strong personal capital, business success for micro entrepreneurs categorized as climbers type can be achieved easily.

\section{CONCLUSIONS}

Journal of Wetlands Environmental Management Vol 8, No 1 (2020) 21 - 32

http://10.20527/jwem.v8i1.215
Partially, Locus of Control, Learning, and Adversity Quotient have significant to the success of micro, small and medium entrepreneurs in Banjarmasin. The effect of Locus of Control $\left(\mathrm{X}_{1}\right)$ on Business Success $(\mathrm{Y})$ is $0.003<0.05$; the effect of Learning $\left(\mathrm{X}_{2}\right)$ on Business Success (Y) is $0.034<0.05$; and the effect of Adversity Quotient $\left(\mathrm{X}_{3}\right)$ on Business Success is $0.00<0.05$. 2). Locus of Control, Learning, and Adversity Quotient are simultaneously influential as indicated by the F count of 51,944 and the F table of 2.68 with a significance of $0,000<0,000.3)$. The dominant effect is shown by the highest tcount value in the Adversity Quotient of 4.924. It means that to improve business success needs has in coaching relating to changes in the mindset and attitudes existing within the entrepreneur's internal themselves so that micro, small and medium entrepreneurs have the fighting power to face and response to each change. It is also supported by strong internal control over any obstacles and sustainable learning.

\section{REFERENCES}

Agustina, Titien; Candrarin, Grahita; Manan, A. (2017). MSMEs Challenges in Phenomena of Disruption Era. Journal of Economics and Sustainable Development, 8(21), 116-121. Retrieved from https://iiste.org/Journals/index.php/JEDS/ article/view/39774/40891

Agustina, T. (2017). Buku Kebangkitan Pengusaha UMKM. Yogyakarta: Aswaja Press.

Agustina, T. (2019). Improving Business Performance through Competitive Advantage: A Study On SMES in Banjarmasin, Indonesia. Eurasia: Economics \& Business, 4(1), 75-84. https://doi.org/.1037//0033-2909.I26.1.78

Agustina, T., Chandrarin, G., \& Manan, A. (2017). Motivation Effect on UMKM Performance in Banjarmasin City: Overview of Locus of Control as a 
Contingency Factor. In Sustainable Development Goals 2030 Challenges and Its Solutons (pp. 978-979).

Agustina, T., Nasution, M. D., \& . S. (2018). Kecerdasan Adversitas dan Kematangan Karir Terhadap Intensi Berwirausaha. Jurnal Riset Inspirasi Manajemen Dan Kewirausahaan, 2(1), 62-72. https://doi.org/10.35130/jrimk.v2i1.31

Bustan, J. (2016). Pengaruh Karakteristik Wirausaha, Orientasi Pembelajaran dan Orientasi Kewirausahaan terhadap Keberhasilan Usaha (Studi Pada Usaha Kecil Pengolahan Pangan Di Kota Palembang). Jurnal Manajemen Dan Bisnis Sriwijaya, 14(1), 29-42. https://doi.org/10.1017/CBO97811074153 24.004

Faizal, N. H. (2007). Ekonomi Manajerial. Jakarta: PT Raja Grafindo Persada.

Fathor, A. S., \& Arief, M. (2017). Pembelajaran Organisasi UKM untuk Menciptakan Keunggulan Bersaing. Jurnal Ekonomi Modernisasi, 13(2), 105118.

Ghozali, I. (2016). Aplikasi Analisis Multivariat Dengan Program SPSS (Kedua). Semarang: Badan Penerbit Universitas Diponegoro.

Hanim, S. \& A. (2002). Evaluasi kesiapan UKM Menyongsong Pasar Bebas Asean (AFTA): Analisis Perspektif dan Tinjauan Teoritis. Jurnal Ekonomi Akuntansi Dan Manajemen, 1(2).

Hendrawan, A., Yulianeu, A., Sucahyawati, H., \& Indriyani, I. (2018). Pengembangan Kompetensi UMKM Dengan Pembelajaran Organisasi. INOBIS: Jurnal Inovasi Bisnis Dan Manajemen Indonesia, 1(4), 489-496. https://doi.org/10.31842/jurnalinobis.v1i4.53

Khandekar, A., \& Sharma, A. (2006). Organizational learning and performance: Understanding Indian scenario in present global context. Education and Training, 48(8-9), 682-692. https://doi.org/10.1108/004009106107100 92
Maulida, S., \& Yunani, A. (2018). Peluang dan Tantangan Pengembangan Usaha Mikro Kecil Menengah (UMKM) Dari Berbagai Aspek Ekonomi. Jurnal Ilmiah Manajemen Dan Bisnis, 2(1), 181-197. Retrieved from https://www.researchgate.net/publication/ 322538819_Peluang_dan_Tantangan_Pen gembangan_Usaha_Mikro_Kecil_Meneng ah_UMKM_Dari_Berbagai_Aspek_Ekon omi

Noersasongko, E. (2005). Program pascasarjana universitas merdeka malang 2005.

Primiana, I. (2009). Menggerakkan Sektor Riil $U K M$ \& Industry. Bandung: Alfabeta.

Rindrayani, S. R. (2016). Strategi pengembangan umkm melalui pembelajaran kewirausahaan sebagai penggerak ekonomi indonesia. SEMINAR NASIONAL MANAJEMEN EKONOMI AKUNTANSI 2016 Unpgri K\KEDIRI.

Riyanti, B.P.D. (2003). Faktor-faktor yang berpengaruh terhadap keberhasilan usaha skala kecil: Suatu studi tentang faktor demografi wirausaha, perilaku inovatif dan inovasi organisasi dari wirausaha yang berhasil. Phronesis, 5, 32-49.

Rotter, J. B. (1966). Generalized Expectancies For Internal Versus External Control of Reinforcement. Psychological Monographs: General and Applied, 80(1), 1-28.

Setiawan, M. N. G. dan R. (2010). Teori-Teori Psikologi. Yogyakarta: Ar-Ruzz Media.

Sholihin, M., \& Mujilahwati, S. (2016). Dampak Pemanfaatan e-commerce terhadap Peningkatan Penjualan di UMKM (Studi Kasus Ninda Bros Lamongan). Jurnal Teknika, 8(1).

Sinkula, J. M., Baker, W. E., \& Noordewier, T. (1997). A framework for market-based organizational learning: Linking values, knowledge, and behavior. Journal of the Academy of Marketing Science, 25(4), 305-318. https://doi.org/10.1177/009207039725400 3

Journal of Wetlands Environmental Management

Vol 8, No 1 (2020) 21 - 32

http://10.20527/jwem.v8i1.215 
Skinner, E., Furrer, C., Marchand, G., \& Kindermann, T. (2008). Engagement and Disaffection in the Classroom: Part of a Larger Motivational Dynamic? Journal of Educational Psychology, 100(4), 765781. https://doi.org/10.1037/a0012840

Slater, S. pdfle. F., \& Narver, J. C. (1994). Market orientation, customer value, and superior performance. Business Horizons, $37(2)$, $22-28$. https://doi.org/10.1016/00076813(94)90029-9

Sony Heru, P. (2009). Mengembangkan Pendidikan Kewirausahaan di Masyarakat. Jurnal PNFI, 1(1), 57-82. Retrieved from http://andragogia.p2pnfisemarang.org/wpc ontent/uploads/2010/11/andragogia1_4.pd $\mathrm{f}$

Stoltz, P. G. (2000). Adversity Quotient @ Work: Make Everyday Challenges the Key to Your Success. New York: William Morrow.

Sudarsono, Bambang \& Irawati, A. (2003). Pengaruh Internal dan External Locus Of Control terhadap Prestasi Usaha Mikro Kecil Menengah Kabupaten Sampang, (Mm), 1-18.

Surekha. (2001). Adversity Intellengence. Jakarta: Pustaka Umum.

Suryana. (2011). Kewirausahaan. Jakarta: Salemba Empat.

Suryaputera, I. (2014). Budaya Kebal Senjata Tajam Dalam Budaya Banjar.
Kompasiana. Retrieved from https://www.kompasiana.com/imizona/55 203dca8133112e0d9dfa27/budaya-kebalsenjata-tajam-dalam-budaya-banjar

Suyanto, C. P. \&. (2010). Motivasi dan Kemampuan Usaha Dalam meningkatkan Keberhasilan Usaha Industri Kecil (Studi Pada Industri Kecil Sepatu di Jawa Timur). Jurnal Manajemen Dan Wirausaha, 12(2), 177-184. https://doi.org/10.9744/jmk.12.2.pp.177184

Tambunan, T. (2002). Perdagangan Internasional dan Neraca Pembayaran: Teori dan Temuan Empiris. Jakarta: LP3ES.

Utami, H. T. (2018). Pengaruh Pengetahuan Pemilik, Skala Usaha, dan Umur Usaha terhadap Keberhasilan Kinerja Usaha dengan Penggunaan Informasi Akuntansi sebagai Variabel Moderasi (Survei pada Pemilik Usaha UKM Makanan Khas di Kabupaten Banyumas). El-Jizya: Jurnal Ekonomi Islam, 6(1), 23-48. https://doi.org/10.24090/ej.v6i1.2044

Wisesa, D., \& Indrawati, K. (2016). Hubungan Adversity Quotient dengan Motivasi Berwirausaha pada Mahasiswa Universitas Udayana yang Mengikuti Program Mahasiswa Wirausaha. Psikologi, Program Studi Kedokteran, Fakultas Udayana, Universitas, 3(2), 187-195. 